\title{
Effect of Press Cycle Time on Application Behavior of Board Made from Chemically Modified Particles
}

\section{Utjecaj trajanja ciklusa prešanja na ponašanje u primjeni ploče izrađene od kemijski modificiranih čestica}

\author{
Original scientific paper • Izvorni znanstveni rad \\ Received-prispjelo: 12. 12. 2014. \\ Accepted-prihvaćeno: 29. 1. 2016. \\ UDK: $630 * 863.215$ \\ doi:10.5552/drind.2016.1443
}

\begin{abstract}
Although acetylation is effective in achieving high hydrophobicity, dimensional stability, and decay resistance of particleboards, springback and mechanical strength loss in modified boards should be improved to maintain high performance of this method. It is questioned if acetylation, due to the hydrophobic nature of modified flakes, could interfere with the polymerization reaction of the phenolic resin. In this research, the effect of different press durations on bioresistance, physical and mechanical behavior of acetylated particleboards at various weight percent gains (WPG) was investigated. Results showed that acetylated boards possessed very low moisture content, water absorption, thickness swelling and biological degradation values compared to control boards. Increasing press time intensified reduction in these boards, with the exception in untreated boards. Also acetylation resulted in high correlation between the springback and the strength losses of the boards due to weak bonding between the wood flakes. Prolongation of the press time in the acetylated boards caused significant reduction in springback and mechanical loss. Regarding the outdoor use with biological degradation for modified boards, an increase in the press time for improving these properties might be recommended.
\end{abstract}

Key words: press time, acetylation, particleboard, thickness swelling, mechanical strength, decay resistance

SAŽETAK • Iako je acetiliranje učinkovit postupak za postizanje visoke hidrofobnosti, stabilnosti dimenzija $i$ otpornosti ploča iverica na propadanje, nužno je spriječiti njezine negativne posljedice kao što je smanjenje mehaničkih svojstava ploča, kako bi se održala visoka učinkovitost te metode. Postavlja se pitanje može li acetilacija zbog hidrofobne prirode modificiranog iverja utjecati na reakciju polimerizacije fenolne smole. U ovom se radu istražuje utjecaj različitog trajanja postupka prešanja na biološku otpornost iverice te fizikalno i mehaničko ponašanje acetiliranih ploča iverica pri različitim postocima porasta težine (WPG). Rezultati su pokazali da acetilirane ploče imaju vrlo nizak sadržaj vode, slabo upijaju vodu, manje debljinski bubre i bolja im je otpornost na biološku razgradnju u usporedbi s kontrolnim uzorcima ploče. Povećanje vremena prešanja poboljšava sva

\footnotetext{
Authors are associate professor and M.Sc. graduated at Department of Wood and Paper Sciences, Faculty of Natural Resources, Sari Agricultural Sciences and Natural Resources University, Sari, Mazandaran, Iran.

${ }^{1}$ Autori su izvanredni profesor i diplomant Odjela za znanost o drvu i papiru, Fakultet prirodnih resursa, Sveučilište poljoprivrednih znanosti i prirodnih resursa, Sari, Mazandaran, Iran.
} 
navedena svojstva, osim u nemodificiranih ploča. Također, acetilacija je rezultirala visokom korelacijom između nereverzibilnog bubrenja i gubitka čvrstoće ploče zbog slabih veza među drvnim iverjem. Produljenje vremena prešanja acetiliranih ploča iverica uzrokovalo je znatno smanjenje bubrenja i gubitak mehaničkih svojstava ploča. S obzirom na vanjsku uporabu ploča iverica i potrebnu otpornost na biološku razgradnju modificiranih ploča, preporučuje se povećati vrijeme prešanja kako bi se poboljšalo svojstvo biološke otpornosti ploča iverica.

Ključne riječi: vrijeme prě̌anja, acetiliranje, ploča iverica, debljinsko bubrenje, mehanička čvrstoća, otpornost na razgradnju

\section{INTRODUCTION \\ 1. UVOD}

The demand for composite wood products, such as particleboard, medium-density fiberboard and veneer board products, has recently increased substantially throughout the world (Sellers, 2000). Particleboards account for $57 \%$ of the total consumption of wood-based panels and their consumption significantly increases each year (Pan et al., 2006). Increasing demand for wood-based panels, along with deforestation and forest degradation, has become an important raw material issue in the wood industry (Colak et al., 2007). Efforts have been made primarily for enhancing the board strength properties, or improving the board dimensional stability and durability under environmental impact (Rowell, 2012). As a result of these concerns, alternative modification methods could play an important role in the manufacture of composite panels such as particleboards with longer service life (Menzies, 2013).

Acetylation as a common modification method to achieve an improvement in particleboard properties, like dimensional stability (Yang et al., 2014; Rowell et al., 2009) or durability (Papadopoulos, 2012; Alfredsen et al., 2013), involves the formation of a covalent bond between the hydroxyl groups of the cell wall polymers of wood and reagent molecules. In order to achieve this, an adequate modification intensity, meaning the relative amount of modification agent added as weight percent gain (WPG), is required (Thybring, 2013).

As known from previous studies, the side effect of acetylation is a decrease in the mechanical properties of particleboards (Wagner et al., 2007, Abdolzadeh et al., 2011), which are mainly caused by low bondability due to low wettability, the loss of a substantial amount of wood per unit mass and deterioration of fibers by acetylation (Korai, 2001). There is an adhesion problem between the hydrophilic water soluble melamine urea formaldehyde (MUF) resin and the hydrophobic acetylated flakes (Wagner et al., 2007). This problem was solved by several methods such as the application of non polar resin with better adhesion to hydrophobic acetylated flakes (Wagner et al., 2007), improvement of the wettability of acetylated flakes by addition of emulsifiers to the phenolic resin (Youngquist et al., 1988), and the increase of panel density (Hague et al., 1999).

It is questioned if acetylation could interfere with the polymerization reaction so that the phenolic resin would not be fully cured during the hot-pressing of the board. This interference may be due to the hydrophobic nature of modified flakes and the concomitant lowering of the heat transfer rate. In this research, the effect of different press cycle times on physical and mechanical behavior was investigated as well as the decay resistance of acetylated particleboards.

\section{MATERIALS AND METHODS}

\section{MATERIJALI I METODE}

\subsection{Acetylation}

2.1. Acetilacija

Flakes were prepared by using a laboratory ring flaker (Pallmam pz8) from maple wood (Acer insigne). They were dried in the oven for $24 \mathrm{~h}$ at $103 \pm 2{ }^{\circ} \mathrm{C}$. After $12 \mathrm{~h}$ soaking in the acetic anhydride, the flakes were heated at $120^{\circ} \mathrm{C}$ for 40 and 180 minutes to achieve 9 and $16 \%$ weight gains, respectively, (based on pre-test results). Modified flakes were washed with distilled water to remove acetic acid as the reaction by-product and unreacted acetic anhydride. Acetylated particles were dried in the oven at $103 \pm 2{ }^{\circ} \mathrm{C}$ for $24 \mathrm{~h}$. Weight percent gain (WPG) was calculated using the equation (1).

$$
W P G=\frac{W_{\text {act }}-W_{\text {unt }}}{W_{\text {unt }}} \cdot 100
$$

Where $W P G$ indicates the weight percent gain $(\%), W_{\text {act }}$ and $W_{\text {unt }}$ are oven dry weights after and before the acetylation $(\mathrm{g})$, respectively.

$\mathrm{OH}$ group's substitution was determined according to equation (2) mentioned in the paper of Li et al. (2011).

$$
O H_{\text {substd }}=\frac{W_{\text {act }}-W_{\text {unt }}}{W_{\text {unt }} \cdot M_{\mathrm{w}}} \cdot 1000
$$

Where $\mathrm{OH}_{\text {substd }}$ indicates substitution of $\mathrm{OH}$ with acetyl groups (mmol/g), $W_{\text {act }}$ and $W_{\text {unt }}$ are oven dry weights after and before the acetylation $(\mathrm{g})$, respectively. $M_{\mathrm{w}}$ is the molecular weight of the adduct acetyl ( $-\mathrm{C}$ (O) $-\mathrm{CH}_{3}$ ) group $(\mathrm{g} / \mathrm{mmol})$.

\subsection{FTIR analysis}

\subsection{FTIR analiza}

The Fourier transform infrared (FTIR) spectra were measured by using a Bio-rad spectrometer FTS40 incorporating a Spectra Tech diffuse reflectance accessory unit. For FTIR analysis, dried acetylated flakes were milled and passed through a 40 mesh sieve. Spectra were obtained directly from wood powder on a detector prism.

\subsection{Manufacture of boards}

\subsection{Proizvodnja ploča}

Particles with size of 20-40 mesh were used for making the particleboards. After being blended with melamine urea formaldehyde (MUF) resin (10\% based on the oven dry weight), the single layer mats were pre- 
Table 1 Duncan Multiple Range Classification of the effect of acetylation and press time on physical and mechanical properties

Tablica 1. Duncanova višestruka klasifikacija raspona utjecaja acetilacije i trajanja prešanja na fizikalna i mehanička svojstva ploča

\begin{tabular}{|c|c|c|c|c|c|c|c|c|c|c|}
\hline WPG, \% & $\begin{array}{c}\text { Press time } \\
\text { Vrijeme prešanja, min }\end{array}$ & WA (2) & WA (24) & TS (2) & TS (24) & SP & MC & MOR & IB & WL \\
\hline \multirow{3}{*}{0} & 4 & B & B & $\mathrm{B}$ & $\mathrm{B}$ & $\mathrm{CD}$ & $\mathrm{A}$ & $\mathrm{A}$ & $\mathrm{A}$ & $\mathrm{AB}$ \\
\hline & 5 & B & $\mathrm{C}$ & $\mathrm{A}$ & $\mathrm{AB}$ & $\mathrm{CD}$ & A & $\mathrm{A}$ & $\mathrm{A}$ & $\mathrm{ABC}$ \\
\hline & 6 & $\mathrm{~A}$ & $\mathrm{~A}$ & $\mathrm{~A}$ & $\mathrm{~A}$ & $\mathrm{BCD}$ & $\mathrm{A}$ & $\mathrm{B}$ & $\mathrm{B}$ & $\mathrm{A}$ \\
\hline \multirow{3}{*}{9} & 4 & $\mathrm{C}$ & $\mathrm{D}$ & $\mathrm{C}$ & $\mathrm{C}$ & $\mathrm{BC}$ & $\mathrm{B}$ & $\mathrm{C}$ & $\mathrm{B}$ & $\mathrm{BC}$ \\
\hline & 5 & $\mathrm{D}$ & $\mathrm{E}$ & $\mathrm{CD}$ & $\mathrm{C}$ & $\mathrm{D}$ & $\mathrm{C}$ & $\mathrm{B}$ & $\mathrm{B}$ & $\mathrm{BC}$ \\
\hline & 6 & $\mathrm{D}$ & $\mathrm{EF}$ & $\mathrm{CD}$ & $\mathrm{D}$ & $\mathrm{CD}$ & $\mathrm{C}$ & $\mathrm{B}$ & $\mathrm{A}$ & $\mathrm{CD}$ \\
\hline \multirow{3}{*}{16} & 4 & $\mathrm{E}$ & $\mathrm{G}$ & $\mathrm{DE}$ & $E$ & $\mathrm{~A}$ & $\mathrm{CD}$ & $\mathrm{D}$ & $\mathrm{C}$ & $\mathrm{D}$ \\
\hline & 5 & $\mathrm{E}$ & FG & $\mathrm{DE}$ & $\mathrm{E}$ & $\mathrm{A}$ & $\mathrm{CD}$ & $\mathrm{D}$ & $\mathrm{C}$ & $\mathrm{D}$ \\
\hline & 6 & $\mathrm{E}$ & $\mathrm{H}$ & $\mathrm{E}$ & $\mathrm{F}$ & $\mathrm{B}$ & $\mathrm{D}$ & $\mathrm{C}$ & $\mathrm{B}$ & $\mathrm{D}$ \\
\hline
\end{tabular}

pared from the treated and untreated chips. Nominal dimension of boards was $400 \times 400 \times 15 \mathrm{~mm}^{3}$ with 3 replications for each treatment. Mat was compressed under 3 $\mathrm{N} / \mathrm{mm}^{2}$ pressure for 4,5 and 6 minutes at the temperature of $175^{\circ} \mathrm{C}$. Target density of the boards was $0.75 \mathrm{~g} / \mathrm{cm}^{3}$.

\subsection{Particleboard properties evaluation}

\subsection{Određivanje svojstava ploča iverica}

The boards were conditioned at $20 \pm 2{ }^{\circ} \mathrm{C}$ and $65 \%$ relative humidity for 2 weeks until they reached equilibrium moisture content. After conditioning, they were cut into test specimens according to DIN 68763, EN 317 and EN113 Standards for mechanical, physical and decay tests, respectively. Five specimens were prepared from each sample board to determine the physical and mechanical properties. Water absorption and thickness swelling after 2 and 24-h immersion were determined. The decay test exposed to Trametes versicolor was carried out in 9 replications for each treatment.

\section{RESULTS AND DISCUSSION}

3. REZULTATI I RASPRAVA

The treatment with acetic anhydride resulted in WPG of $9 \%$ and $16 \%$. Since unreacted chemicals from treated flakes were removed after the treatment, the WPG of modified samples after treatment indicated the evidence of chemical reactions. Statistical analysis of physical, mechanical and biological data were conducted using factorial design. Means of each treatment were compared according to Duncan multiple range test at $p \leq 0.05$.

\subsection{Changes in chemical structures of wood after acetylation}

3.1. Promjene kemijske građe drva nakon acetilacije

By increasing the reaction time, more intensity levels of modification (WPG) with acetic anhydride were obtained. Esterification of maple particles was established by the increase in weight (Table 2) and infrared spectroscopy (Fig. 1). It can be seen that at $9 \%$ and $16 \%$ weight gains, 2.09 and $3.70 \mathrm{mmol}$ of $\mathrm{OH}$ groups per gram of wood are substituted, respectively, when reacted with acetic anhydride.

Infra-red spectra confirmed the occurrence of wood-acetic anhydride reaction. The strong intensity
Table 2 Reaction conditions and number of substituted hydroxyl groups in different acetylation levels

Tablica 2. Uvjeti reakcije i broj supstituiranih hidroksilnih skupina pri različitim stupnjevima acetilacije

\begin{tabular}{|c|c|c|c|}
\hline $\begin{array}{c}\text { Time } \\
\text { Vrijeme } \\
\text { min }\end{array}$ & $\begin{array}{c}\text { Temperature } \\
\text { Temperatura } \\
{ }^{\circ} \mathrm{C}\end{array}$ & $\begin{array}{c}\text { Weight gain } \\
\text { Porast težine } \\
\%\end{array}$ & $\begin{array}{c}\text { OH groups } \\
\text { substitution } \\
\text { Supstituirane } \\
\text { OH skupine } \\
\mathrm{mmol} / \mathrm{g}\end{array}$ \\
\hline 0 & 0 & 0 & 0 \\
\hline 40 & 120 & 9 & 2.09 \\
\hline 180 & 120 & 16 & 3.70 \\
\hline
\end{tabular}

obtained in the region of $1738 \mathrm{~cm}^{-1}$ was due to the increased symmetric stretching of carbonyl group $(\mathrm{C}=\mathrm{C})$ of the acetyl group after treatment. This observation was confirmed by an increase in the intensities of absorption bands at $1245 \mathrm{~cm}^{-1}(\mathrm{C}-\mathrm{O})$ and $1376 \mathrm{~cm}^{-1}$ $\left(\mathrm{CH}_{3}\right)$. As expected, such absorption was not present in unmodified wood (marked C, on Fig. 1). Also, the substitution of hydroxyl groups can be seen by FTIR spectroscopy. The accompanying decrease in the intensity of the broad band at $3413 \mathrm{~cm}^{-1}$ was also noticed, indicating that the hydroxyl group's content was decreased. The changes in the characteristic absorption bands in the infrared spectrum of treated wood verified that hydrophobic acetyl groups replace the hydrophilic hydroxyl groups of wood after acetylation.

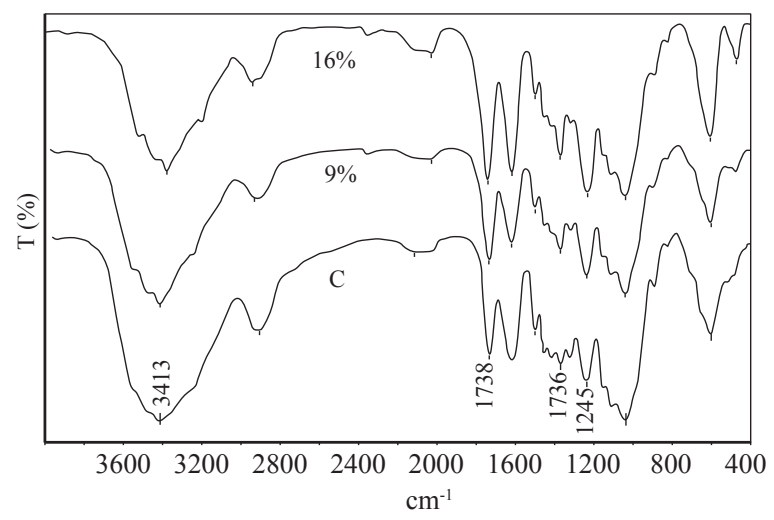

Figure 1 FTIR spectra of maple wood treated with acetic anhydride at different intensities

Slika 1. FTIR spektar javorova drva s anhidridom octene kiseline u različitom intenzitetu 


\subsection{Physical properties}

\subsection{Fizikalna svojstva}

In the 2-h water-soaking test, acetylated boards had very low average water absorption (WA) and thickness swelling (TS) values compared to control boards (Fig.2\&3). The WA and TS of the boards decreased with the increase of acetylation level. The average of WA and TS value in acetylated boards at $16 \%$ WPG and $4 \mathrm{~min}$ press were $66 \%$ and $63 \%$ less, respectively, than that obtained for unmodified boards. Increasing press time from 4 min to 6 min reduced WA and TS in most cases, with a few exceptions in untreated boards. Similarly, in a 24-h water soaking test, WA and TS values were decreased significantly by acetylation. After 24-h soaking in water, WA of modified boards at $9 \%$ and $16 \% \mathrm{WPG}$, and $6 \mathrm{~min}$ compared to $4 \mathrm{~min}$ press time, was reduced by $19.8 \%$ and $29.8 \%$, respectively. Also, for the same soaking period, reduction trend of thickness swelling in modified boards with different press times was observed.

Due to reducing the number of hydroxyl groups and the occupation of intermolecular space in the wood cell wall, so called "bulking effect", acetylation decreases the hygroscopicity of wood cell wall and consequently increases the dimensional stability of the

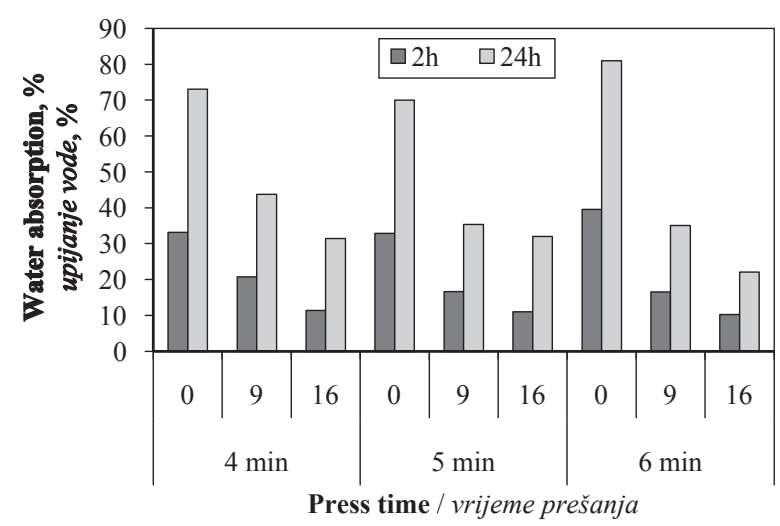

Figure 2 Effect of press time on water absorption of acetylated particleboards (WPG: $0 \%, 9 \%$ and $16 \%$ ) Slika 2. Utjecaj trajanja prešanja na upijanje vode acetiliranih ploča iverica (WPG: $0 \%, 9 \%$ i $16 \%$ )

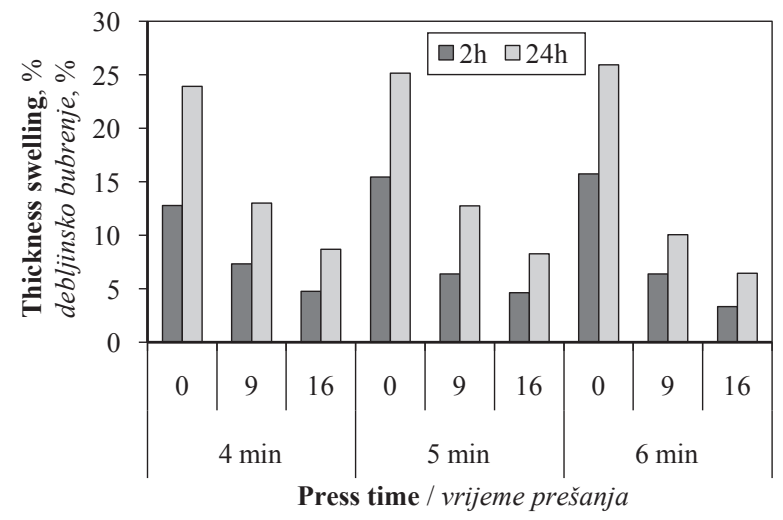

Figure 3 Effect of press time on thickness swelling of acetylated particle boards (WPG: $0 \%, 9 \%$ and $16 \%$ ) Slika 3. Utjecaj trajanja prešanja na debljinsko bubrenje acetiliranih ploča iverica (WPG: $0 \%, 9 \%$ i $16 \%$ )

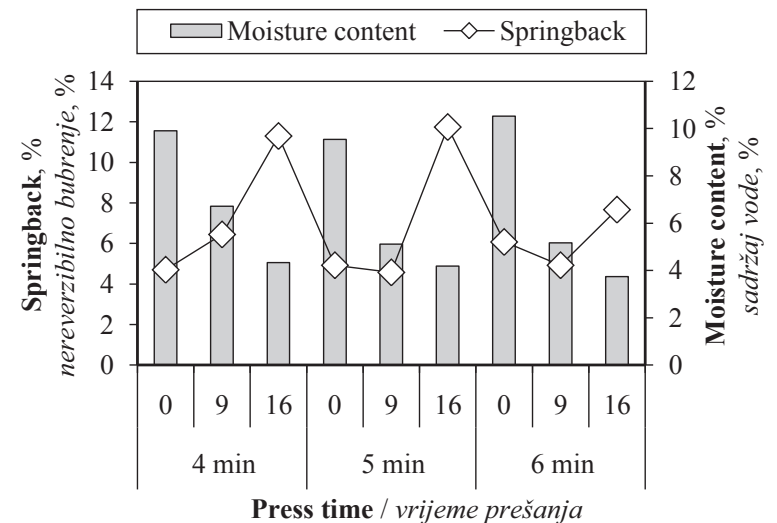

Figure 4 Effect of press time on springback and moisture content of acetylated particleboards (WPG: $0 \%, 9 \%$ and $16 \%)$

Slika 4. Utjecaj trajanja prešanja na nereverzibilno bubrenje i sadržaj vode acetiliranih ploča iverica (WPG: $0 \%, 9 \%$ i $16 \%$ )

particleboards (Sander et al., 2003; Rowell, 2005; Hill, 2006). Results showed that acetylated boards had very low water absorption and thickness swelling values in water compared to control boards. Increasing press time intensified reduction in water absorption and thickness swelling in most cases, with a few exceptions in untreated boards. These findings also confirm the results presented by other authors (Yang et al., 2014; Rowell et al., 2009, Rowell, 2006).

A change in moisture content and springback of modified boards compared with untreated samples could be observed after conditioning (Fig. 4). The MC in the modified boards was reduced as the WPG increased. It was also revealed that the acetylation affected springback of the boards and caused significant increase as the WPG increased in the boards. Increase of the press time in the acetylated boards caused significant reduction in $\mathrm{MC}$ and springback.

Springback is an irreversible thickness swelling, which occurs after wetting of the composites or releasing of stresses accompanied by some loss of glue bonds (Mohebbyet al., 2009). According to the results, the MC in the modified boards, inverse springback, was reduced as the WPG increased. Therefore, the springback of the boards was affected by the acetylation because of the interfering bonding between aqueous-based resin and the modified wood element due to low wettability, weaker bonding because of incomplete curing of resin in the core layer and lower compression in stiffer and denser mat (Vick and Rowell, 1990; Vick and Krzysik, 1991). It was reported that the majority of the failures in the acetylated wood composites was shown between resin and wood due to their hydrophobic nature; however, the failure in the control group of specimens occurred in the wood (Papadopoulos and Hill, 2002). Increase of the press time in the acetylated boards caused significant reduction in springback after conditioning.

\subsection{Mechanical strength}

3.3. Mehanička čvrstoća

The bending and bonding strength of chemically modified particleboards in different press times are 


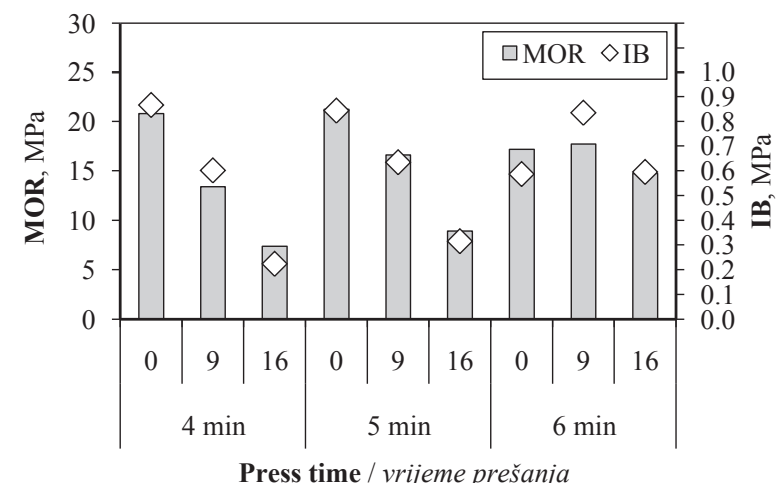

Figure 5 Effect of press time on mechanical strength of acetylated particleboards (WPG: 0\%, 9\% \& 16\%)

Slika 5. Utjecaj trajanja prešanja na mehaničku čvrstoću acetiliranih ploča iverica (WPG: $0 \%, 9 \%$ i $16 \%$ )

summarized in Table 2. Unfortunately, at the 4 minutes press time, the mechanical stability of modified boards was lower than that of the control particleboard (Fig. 5). The bending and bonding strength decreased as the acetylation levels increased. Even a low degree of acetylation results in a high decrease of the mechanical strength of the board. By increasing press time to 6 minutes, IB raised $27.9 \%$ and $62.4 \%$ at 9 and $16 \%$ WPG, respectively. In this condition, the MOR was improved by $24.3 \%$ and $49.8 \%$.

The bending and bonding strength of the board decreased as the acetylation levels, which were somewhat compensated with prolongation of the press time, increased. Decrease in mechanical strength is caused by the substantial loss of wood due to the application of heat and generation of the acetic acid (Hill, 2006), decreased surface wetting, unsuitable dispersion of resin, and low bondability between the polar resins and the apolar acetylated wood flakes (Korai, 2001; Wagner et al., 2007; Abdolzadeh et al., 2011). Also, stiffer and denser acetylated particles need more moisture and pressure during hot pressing.

\subsection{Decay resistance}

\subsection{Otpornost na propadanje}

The biological behavior of acetylated particleboards with different press times against white rot fungi is presented in Fig. 6. It can be observed that the highest loss of weight was recorded on the untreated boards $(46.29 \%)$ at 6 minutes press time. The data from decay test indicates a positive relationship between the extent of modification and decay resistance (Fig. 6). Particleboards, modified with acetic anhydride at the highest modification level, showed the most significant improvement in decay resistance $(1.90 \%$ weight loss). Increasing press time reduced weight loss of acetylated samples by 17.5 and $53 \%$ at $9 \%$ and 16 $\%$ WPG, respectively.

Many researchers report that acetylation causes a good bioresistance of particleboards (Ghorbaniet al., 2010). The mechanism of biological resistance of acetylated wood is not completely understood. However, the resistance is believed to be due to several established theories of mode of action in modified wood:

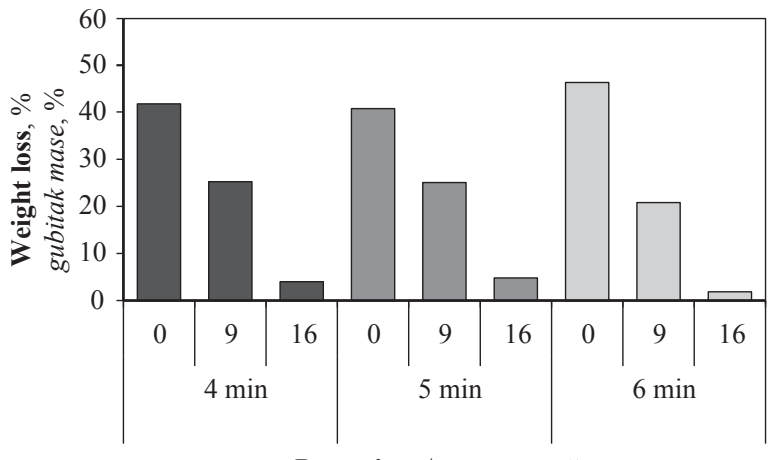

Press time / vrijeme prě̌anja

Figure 6 Effect of press time on weight loss of acetylated particleboards (WPG: $0 \%, 9 \%$ and $16 \%$ )

Slika 6. Utjecaj trajanja prešanja na gubitak mase acetiliranih ploča iverica (WPG: 0\%, 9\% i $16 \%$ )

inhibition of diffusion of fungal enzyme molecules because of the decreasing moisture amount in wood (Boonstra and Tjeerdsma, 2006) and micro pore blocking (Hill et al., 2005); and decay enzyme inefficiency due to unrecognizable substrate as a food source (Rowell, 2005).

Although acetylation is effective in achieving high hydrophobicity, dimensional stability, and decay resistance, springback and mechanical strength loss due to low bondability should be improved to maintain high performance of this method. According to the previous research (Bavaneghi and Ghorbani, 2015), acetylation decreases the heat transfer to the core layer. Therefore, delay in the heat transfer increased the springback and loss of mechanical properties because of incomplete resin curing. During the hot-pressing, the generated steam from both free and bound water in wood particles and the water in the resin are driven to the mat core (Vick and Rowell, 1990), and the thermosetting adhesives are polymerized throughout the panel.

Acetylation affects the conduction and convection, as the most important mechanisms for heat transfer in the hot press (Rowell, 2005), through the reduction in the hydrophilicity of the lignocellulosic material (Li et al., 2007), bound water in cell walls and free water in lower porosity. All of these reasons directly affect the temperature of the core layer. By increasing the press time, the resin in the core layer could be cured with the rising of the final temperature of the core layer. The increase of hot press time of the particleboard production improved resin curing and bonding and reduced springback. Stronger bonding between modified flakes caused more improvement in water resistance, thickness swelling and decay resistance due to decreased porosity.

Regarding the outdoor use with biological degradation, an increase in the press time for improving these properties might be recommended. For future research, focus should be placed on the effect of utilization of hydrophobic resin like isocyanate, more attention should be paid to the higher pressure in hot press and the mat moisture for producing particleboards with higher mechanical strength should be increased. 


\section{CONCLUSION}

\section{ZAKLJUČAK}

Esterification of maple particles was established by the increase in weight and infra-red spectroscopy. According to the results, press time had significant effect on the physical, mechanical and biological properties of acetylated particleboards. The following can be concluded:

1. Water absorption and thickness swelling values were significantly reduced by acetylation. Prolongation of press time improved water resistance and thickness swelling due to stronger bonding between modified flakes and less porosity.

2. Treatment of acetylation on flakes resulted in a remarkable loss in MOR and IB values and an increasing springback. The higher press time of the particleboard manufacturing process improved mechanical properties and thickness stability because of achieving the required temperature for resin curing in core layer and reinforce bonding.

3. The decay test indicates a positive relationship between the extent of modification and decay resistance. Increasing press time reduced weight loss of acetylated boards by improving resin curing, and stronger bonding between modified flakes resulted in decreased porosity.

\section{REFERENCES}

\section{LITERATURA}

1. Abdolzadeh, H.; Doosthoseini, K.; Karimi, A. N.; Enayati, A. A., 2011: The effect of acetylated particle distribution and type of resin on the physical and mechanical properties of poplar particleboard. European Journal of Wood and Wood Products, (69): 3-10 http://dx.doi.org/10.1007/s00107-009-0390-5.

2. Alfredsen, G.; Flate, P. O.; Militz, H., 2013: Decay resistance of acetic anhydride modified wood: a review. International Wood Products Journal, (3): 137-143 http://dx.doi.org/10.1179/2042645313Y.0000000034.

3. Boonstra, M. J.; Tjeerdsma, B., 2006: Chemical analysis of heat treated softwoods, HolzRohWerkst, (64): 204$211 \mathrm{http}: / / \mathrm{dx}$. doi.org/10.1007/s00107-005-0078-4.

4. Bavaneghi, F.; Ghorbani, M., 2015: Mechanical behavior and springback of chemical modified particleboard made in different press times. Wood material science and engineering.

http://dx.doi.org/10.1080/17480272.2015.1006249.

5. Colak, S.; Colakoglu, G.; Aydın, I.; Kalaycioglu, H., 2007: Effects of steaming process on some properties of eucalyptus particleboard bonded with UF and MUF adhesives. Build. Environ., 42 (1): 304-309.

6. Ghorbani, M.; Doosthoseini, K.; Karimi, A. N.; Mohebby, B.; Asghari, H., 2010: Biological resistance of acetylated particleboards exposed to white (Trametesversicolor (and brown (Coniophoraputeana) rot fungi. International Research Group on Wood Protection. IRG/ WP 10-40534.

7. Hague, J.; Robson, D.; Riepen, M., 1999: MDF process variables - An overview of their relative importance,in: 33rd Inter. Particleboard / Composite Materials Symp. Proc., Wash. State Univ., Pullman, Wash. 13-15, 79-87.

8. Hill, C. A. S.; Forster, S. C.; Farahani, M. R. M.; Hale, M. D. C.; Ormondroyd, G. A.; Williams, G. R., 2005: An investigation of cell wall micropore blocking as a possible mechanism for the decay resistance of anhydride modified wood. Int. Biodeter. Biodegrad, (55): 69-76.

9. Hill, C. A. S., 2006: Chemical modification of wood (I): Acetic anhydride modification, in: Wood modification: Chemical, Thermal and other processes, C. A. S. Hill (ed.), John Wiley and Sons, London. p 260 http://dx.doi.org/10.1002/0470021748.

10. Korai, H., 2001: Effects of low bondability of acetylated fibers on mechanical properties and Dimensional stability of fiberboard, J Wood Sci, (47): 430-436 http://dx.doi.org/10.1007/BF00767894.

11. Li, X.; Tabil, L. G.; Panigrahi, S., 2007: Chemical Treatments of Natural Fiber for Use in Natural Fiber-Reinforced Composites: A Review, J Polym Environ. (15): 25-33 http://dx.doi.org/10.1007/s10924-006-0042-3.

12. Li, Y.; Dong, X.; Liu, Y.; Li, J.; Wang, F., 2011. Improvement of decay resistance of wood via combination treatment on wood cell wall: swell-bonding with maleic anhydride and graft copolymerization with glycidyl methaacrylate and methyl methaacrylate. International Biodeterioration \& Biodegradation, 65 (2011): 10871094 http://dx.doi.org/10.1016/j.ibiod.2011.08.009.

13. Menzies, G. F., 2013: Whole Life Analysis of timber, modified timber and aluminium-clad timber windows: Service Life Planning (SLP), Whole Life Costing (WLC) and Life Cycle Assessment (LCA), Edinburgh: HeriotWatt University.

14. Mohebby, B.; Ghorbani-Kokande, M.; Soltani, M., 2009: Springback in acetylated wood based composites. Construction and Building Materials, 23 (9): 3103-3106 http://dx.doi.org/10.1016/j.conbuildmat.2009.02.007.

15. Pan, Z.; Cathcart, A.; Wang, D., 2006: Properties of particleboard bond with rice bran and polymeric methylene diphenyldiisocyanate adhesives, Ind. Crops Prod. 23 (1): 40-45 http://dx.doi.org/10.1016/j.indcrop.2005.03.004.

16. Papadopoulos, A. N.; Hill, C. A. S., 2002: The biological effectiveness of wood modified with linear chain carboxylic acid anhydrides against Coniophoraputeana. HolzRohWerkst., (60): 329-332 http://dx.doi.org/10.1007/s00107-002-0327-8.

17. Papadopoulos, A. N., 2012. Natural durability of acetylated OSB in ground stake test: total decay after 102 months of testing, European Journal of Wood and Wood Products, (70): 397 http://dx.doi.org/10.1007/s00107-011-0547-x.

18. Rowell, R. M., 2005: In handbook Wood Chemistry and Wood Composites, Taylor \& Francis, Boca Raton, FL, $487 \mathrm{pp}$.

19. Rowell, R. M., 2006. Chemical modification of wood: a short review, Wood Material Science and Engineering. 1 (1): $29-33$ http://dx.doi.org/10.1080/17480270600670923.

20. Rowell, R. M.; Ibach, R. E.; McSweeny, J.; Nilsson, T., 2009. Understanding decay resistance, dimensional stability and strength changes in heat-treated and acetylated wood. Wood Mat. Sci. Eng, (4): 14-22 http://dx.doi.org/10.1080/17480270903261339.

21. Rowell, R. M., 2012: Chemical modification of wood to produce stable and durable composites. Cellulose Chem. Technol., 46 (7-8): 443-448.

22. Sander, C.; Beckers, E. P. J.; Miltiz, H.; Vanveenendaal, W., 2003: Analysis of acetylated wood by electron microscopy. Wood Science \& Technology, (37): 39-46 http://dx.doi.org/10.1007/s00226-002-0160-6.

23. Sellers, T., 2000: Growing markets for engineered products spurs research.Wood Technol., 127 (3): 40-43. 
24. Thybring, E. E., 2013: The decay resistance of modified wood influenced bymoisture exclusion and swelling reduction, International Biodeterioration\& Biodegradation, 82 (2013): 87-95.

25. Vick, C. B.; Rowell, R. M., 1990: Adhesive bonding of acetylated wood. Int J Adhes, 10 (4): 263-272 http://dx.doi.org/10.1016/0143-7496(90)90044-X.

26. Vick, C. B.; Krzysik, A., 1991: Acetylated, isocyanatebonded flakeboards after accelerated aging: dimensional stability and mechanical properties, HolzalsRoh- und Werkstoff, (49): 221-228.

27. Youngquist, J. A.; Rowell, R. M., 1986: Mechanical properties and dimensional stability of acetylated aspen flakeboard.HolzalsRoh- und Werkstoff, (44): 453-457.

28. Wagner, D.; Schwarzinger, C.; Leidl, M.; Schmidt, H.; Endesfelder, A., 2007: Particleboards from Acetylated Wood Flakes. Monatshefte fur Chemie, (138): 321-325 http://dx.doi.org/10.1007/s00706-007-0607-4.

29. Yang, C. N.; Hung, K. C.; Wu, T. L.; Yung, T. C.; Chen, Y. L.; Wu, J. H., 2014: Comparisons and characteristics of slice wood acetylation with acetic anhydride by liquid phase, microwave, and vapor phase reactions. BioResourses, 9 (4): 6463-6475.
30. *** DIN Standard (No. 68763). 1990. Flat pressed particleboard for use in building construction,

31. *** EN 113, 1996. Wood preservatives. Method of test for determining the protective effectiveness against wood destroying basidiomycetes - determining of the toxic values, BeuthVerlag GmbH, Berlin, $25 \mathrm{pp}$.

32. *** EN 317, 1993. Particleboards and fiberboard Dertermination of swelling in thickness after immersion in water, BeuthVerlag GmbH, Berlin, 5 pp.

\section{Corresponding address:}

\section{Assoc. Prof. MARYAM GHORBANI}

Department of Wood and Paper Sciences

Faculty of Natural Resources

Sari Agricultural Sciences and Natural Resources

University

P.O. Box: 48181068984, Sari

Mazandaran, IRAN

e-mail: ghorbani_mary@yahoo.com 